\title{
Black English and the New Cosmopolitanism: Karima 2G's Linguistic Creativity as a Transethnic Performative Practice
}

A cultural turn started in the 1980s and led to a focus shift in linguistics, moving from merely linguistic issues-centered on the study of a word/text-to a conception of language as an integral part of a cultural, literary, historical and ethic-anthropological system. More specifically, both the recent and constant migration flows and the oldest colonial conquerors contributed to a progressive rethinking of concepts like language, translation, belonging, mobility, contact, nation, identity, and community; as well as to an analysis of the socio-linguistic and cultural implications of such categories in the lands of arrival. In particular, by creating a connection between the history of the African American diaspora and the present trans-Mediterranean migrations towards Italy, the theoretical reflection here proposed is centered on the emergence of new patterns of description and interpretation of a closed reality, with the aim of re-considering new linguistic and cultural scenarios, marked by a momentous change of paradigm.

From a strictly linguistic point of view, an illustrative example of this change would be the forming of new geo-localities and linguistic identities, represented by second-generation immigrants using African American English in Italy as a form of pidgin for communicative purposes that go beyond all linguistic, national and geographical borders. In particular, this unprecedented case study will be the rap written and interpreted by the African Italian Anna Maria Gehnyei, a.k.a. Karima 2G, whose new cosmopolitan performance and narration will guide us through the linguistic and cultural history of the color line in Italy. This will be possible thanks to her story: that of a second-generation Liberian Italian, rapping and playing with Black English or, as she likes to define it, Pidgin English, offering us a transatlantic vision of the traces left by the memory of the African diaspora. The semiotic-linguistic repertoire of her $2 G$ album creates an image of the African in Italy based on Blackness as a performance of temporary identity, culture and language, and of rap as a form of criticism, resistance and denunciation of all of practices of racial repression. A thorough analysis of her repertoire triggers a reflection on the new forms of 'Italianness', that need to be constructed using a comparative approach, looking at the way the discourses on the color line coming from the United States interact with the Italian paradigms of language, identity and race.

By moving the color line towards a Black Italian imagery, Karima $2 \mathrm{G}$ uses her rap to question the respective factors and responsibilities when it comes to one's roots, be they white, black, mixed, English speaking, or non-English speaking, thus reflecting on the political meaning of linguistic and cultural crossings. Such a reflection focuses on the 
question of whether and how diasporic and postcolonial English speakers can creatively negotiate place, space, and identity through Black English, adopting trans-idiomatic uses and contexts that are configured as alternatives to national communities, eventually sketching a transnational vision of Italianness-one capable of including not only those who have always been Italian, but also those who have become Italian recently, as well as those who at some point-or to some extent-have stopped being Italian.

\section{Long Live Pidgin English: The Creative Language of Karima 2G}

Karima 2G's linguistic, identity, cultural and musical route is particularly meaningful thanks to the fact that she belongs to both the Liberian and US cultures, and because she witnessed a history of colonization and of both old and new diasporas connecting Africa, the United States, and Italy. Karima $2 \mathrm{G}$ is an Italian rapper, singer, songwriter and beatmaker of Liberian origin, born in Rome in 1980. In 2010, she founded the PepeSoup duo with the DJ/Producer Cukiman, mixing with elegance the rhythms of West Africa, drawing from countries such as Nigeria, Ghana, Senegal, Liberia, and Ivory Coast. In 2011 Karima 2G was selected by Al-Jazeera for a pro-integration project called Surprising Europe, joining other artists from across Europe. In 2013 she went to Liberia, discovering her roots. By the time she returned to Italy, she had acquired a new awareness of her origins, which she expresses through music and by committing to the cause of integration and the right to second-generation citizenship in Italy. In 2014 she released her debut solo album 2G (Soupu Music), written and produced by Karima 2G in Pidgin English, her mother tongue. She is now a student of political and communication science at the John Cabot University of Rome.

Her language, as well as her Liberian origin, takes us back to a United States colonial experience from 1820 which involved the American Colonization Society, an organization formed by rich slaveholders from the South to relocate freed slaves to Africa. Subsequently, the organization obtained from local leaders permission for African Americans to settle down in the Capo Mesurado area, which became known as Liberia in 1824. The fast-growing colony obtained independence in 1847. African Americans, and their descendants, were a privileged caste that had full political and economic power, without having to integrate with the local population. The bond with the United States granted access to North American political relationships and trade routes, but integration always remained a complex issue (Juang and Morrissette 692-695).

In the story of Karima $2 \mathrm{G}$, the first hint of her colonial heritage is her contact with the language of the African American colonizers in Liberia, the Black English inherited by her parents, used as a pidgin for communicative purposes and beyond linguistic, national, and geographical borders. This section will concentrate on the 
formation of new geo-localities and linguistic identities emerging from the multiple contaminations and exchanges among cultures in movement, as well as on the creative use of English in Karima 2G's rap. In particular, it is worth quoting some extracts from an interview that included questions concerning her relationship with her mother tongue:

My mother tongue is Pidgin English. This language is used in Liberia, my land of origin, as well as in other parts of West Africa. My parents have used Pidgin English with me since when I was a child. Their purpose has always been that of teaching me the importance of the traditions and customs of their cultures. They could not teach me both of their dialects (Grebo for my mother and Kpelle for my father), given the difficulty and the differences between the two, so they used Pidgin English as a common language. However, since I was born in Rome and have lived there for a long time, I also speak 'Romano' at home. (Personal Interview) ${ }^{112}$

Pidgin English becomes a sort of lingua franca in the family context of Karima 2G. This affective bond with the mother tongue remains unbreakable, despite Karima being born and raised in Italy. Her choice of writing and rapping in Pidgin English, in spite of being perfectly proficient in Italian, has an unprecedented aesthetic and political value, as well as being an emblematic example of "flexible bilingualism" (Creese and Blackledge), in which the concept of identity is central and complex: "When you have two identities you have on the one hand a greater richness, on the other it is more difficult to find a synthesis, to represent it as a whole" (Karima 2G). Her dual culture becomes the leitmotiv of her solo album, which is intentionally called $2 G$, a label to which the artist is strongly opposed. It is used in Italy to define second generations, drawing from a repertoire of discriminating discourses and narrations related to the entitlement to citizenship based on ius sanguinis and not on ius soli. ${ }^{113}$ Thus, it is not by chance that her album $2 G$, released in 2014, came right in the middle of the debate concerning citizenship, migration flows from Africa on the Mediterranean routes, and embarrassing episodes of racism perpetrated by Italian politicians such as Roberto Calderoli. In the song Orangutan, Karima $2 \mathrm{G}$ replies with her desecrating and ironic rap, drawing from the African American practice of signifyin', to the arro-

112 This and the following extracts have been translated into English by the author and come from email interviews carried out by the author with Karima 2G between February and September 2016, partly published in Italian in Taronna, "Black Power."

113 As of this writing (April 2017), the new law proposed to modify the existing law on Italian citizenship has not been approved by the Senate, despite the approval by the Chamber of Deputies at the end of 2015. A campaign was launched in 2011, "L'Italia sono anch'io" [Italy is me, too]: (www.litaliasonoanchio.it/index.php?id=522) and, more recently, the appeal "\#italiani senza cittadinanza" was launched [citizenship-less Italians]: (www.facebook.com/italianisenzacittadinanza/), through which a network of associations, syndicates, and citizens collected signatures from thousands of petitioners asking for a reform that would grant the citizenship to those children born in Italy from foreign parents, as well as granting them, as well as those persons who have consistently lived in Italy for at least five years the right to vote in city council elections. 
gance of former Minister Roberto Calderoli who, in 2003, declared that it was not possible for Italy to let immigrants vote because "a civil country cannot give the right to vote to some bingo-bongos, who have been living in trees until a few years ago." Ten years later, during a conference of his party Lega Nord, Roberto Calderoli draws from the racist repertoire of wilderness once again-defining the former Minister for Integration Cécile Kyenge as an “orangutan.” Karima 2G then raps about the caricatured image of Africans conveyed by some Italian politicians:

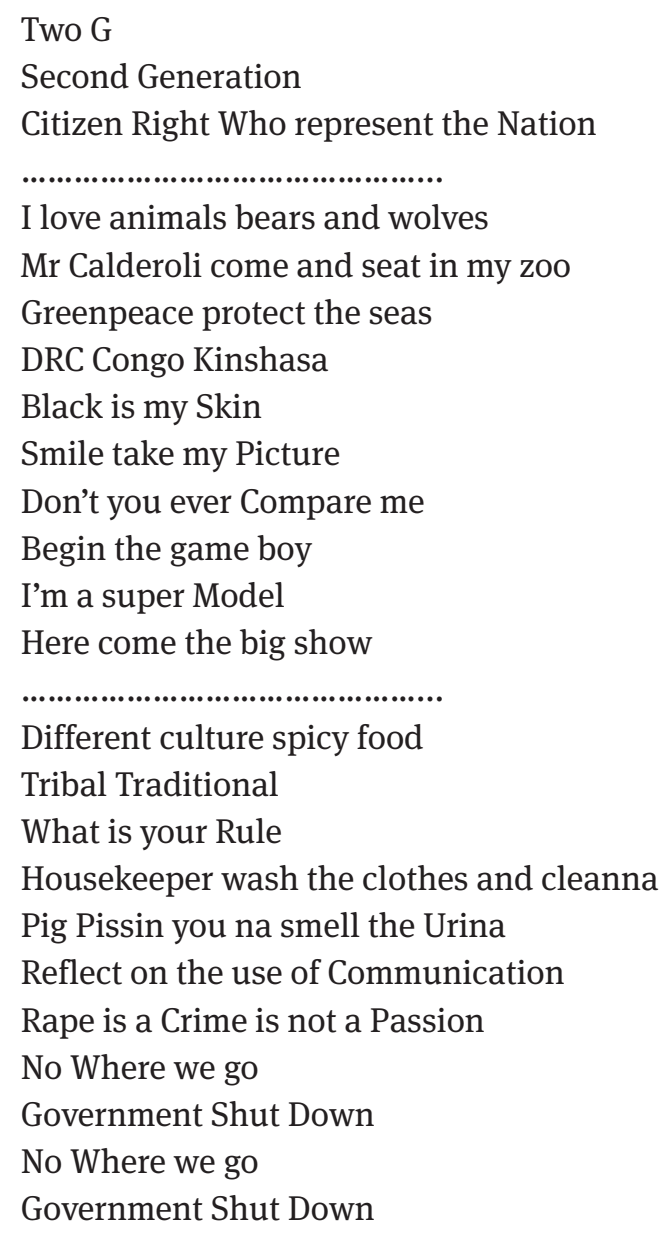

The song is an answer to the verbal aggression against Kyenge- "caused" in 2013 by her proposal consisting of abrogation of the Bossi-Fini law, decriminalization of "illegal immigration," abolition of score-based residency permits, closing-down of CIE, and passage from ius sanguinis to ius soli for obtaining Italian citizenship. Its lyrics unveil the historical and symbolic bond between the keeping of a clear color line in Italy and the fear of mixing races. As noted by Gaia Giuliani (172), the taboo of mixed race is central in the definition of the imagined Italian community because it would represent a border-crossing image, embodying both the evidence and the violation of racial hierarchies, with their precise definition of who must be at the top, as well as the degradation of an alleged whiteness through (sexual/biological) contact with blackness. 
From an exclusively linguistic point of view, the lyrics contain some phonetic and morpho-syntactic features found in both Liberian English and African American English. To mention some, the replacement of the voiced velar stop [g] in the group [ing] with the nasal alveolar [n], e.g. pissing becomes pissin, a common feature of other regional varieties in the southern United States; the disappearance of the approximant postalveolar $[\mathrm{r}]$ in postvocalic position, e.g. cleaner $\rightarrow$ cleanna; the simplification of consonant clusters, e.g. picture $\rightarrow /$ 'prktfa/, culture $\rightarrow$ /'knltfa/; phonetical reduction of -er group into the vowel sound -a, e.g. housekeeper $\rightarrow /$ 'havs,ki:pa/; vowel strengthening in the pronunciation of the verb compare / $\mathrm{kəm}$ 'pcə/ in / kəm'ppa/. Among morpho-syntactic features, it is worth mentioning the reiterated third person singular without the final -s (e.g.: "Greenpeace protect the sea, here come the big show, housekeeper wash, government shut down"), also found in other regional varieties of American English, albeit mostly as an episodic usage-while it is an integral part of Black English. A very interesting case worth discussing is the use of the auxiliary $n a$, in the verse "Pig Pissin you na smell the Urina," explained by the artist in the following terms: "The particle na, as I used it, means had. It must be said that this particle is used for emphasizing a statement and it is especially common in Nigeria, as well as in Sierra Leone and Ghana. The standard version of the sentence is: You had smelt the Urina."

In order to explain the use of the particle $n a$, it is necessary to go back to the origins of Pidgin English. It is a complex story, based on various sources and reconstructions that tend to call it, more scientifically, Liberian English (LibE), whose evolution, diachronically speaking, was marked by five crucial factors (Singler 252-255): 1 . The spread of an English-based pidgin, born for trade reasons during the seventeenth century on the Liberian coasts; 2 . The birth of Kru seamanship in the end of the nineteenth century; 3. the settlement of freed African American slaves in the nineteenth century; 4. The spread of English at the beginning of the twentieth century; 5 . The constant influences coming from the Niger-Congo languages spoken in the country.

The intertwining of these factors caused the emergence of differences between LibE and African American English, such as the use of the completive-perfective auxiliary $n a$ with a double meaning. In fact, it can be used as an auxiliary in past perfect formation (e.g.: LibE: "the woman think the children na die" $0 \neq$ StE: "The woman thought that the children had died"), and also as an adverb expressing time (LibE: "Nobody know where he take the deed from, ha na bring it" $\neq$ StE: "Nobody knew where he got the deed from that he now produced").

Disambiguation between the two acceptations is not always easy, also given the co-existence of at least three hypotheses explaining its origin. According to Singler, the first "substrate" hypothesis links the use of $n a$ to a Kru language, more specifically to Dewoin (249-274). The second hypothesis underlines the homophony between na and now. A further connection between the two would be the fact that in LibE the auxiliary na is often spelled now. More possible evidence of the connection between na and now is the fact that, as stated by some speakers, the two forms cannot coexist 
in the same sentence. According to a third hypothesis, na might derive from the auxiliary don (done), often found in other pidgin and creole varieties of West Africa. Even more crucially, this derivation would mean a connection with African American English, the base upon which LibE developed (also called 'Settler English') from the nineteenth century onwards. In Liberia, the use of don (done) is an affective mark linked to the identity of the colonizer. From a rhetorical point of view, it must be said that the verse Pig Pissin you na smell the Urina is clearly referred, with a metaphorical and challenging intent, to the Italian party Lega Nord, whose members have enacted racist and violent imprinting practices against mosques and Muslim cultural centers. In particular, Karima $2 \mathrm{G}$ is talking about what happened in Boulogne in 2011, when some Lega Nord affiliates threatened to pour pig urine on land destined for the building of a mosque. ${ }^{114}$ The image evoked by the rapper in this verse, just as explosive as the language used, can be regarded as a concrete example of the typically black rhetoric that Zora Neale Hurston defined "will to adorn.” Here, the will to adorn stems from the expressive strength of Karima 2G, who does not just name an object, an episode or a person, but indeed she illustrates her reference and criticizes it, thanks to a mise en scene made of action words.

On a more specifically visual level, the video has a pedagogical function, embodied by the repertoire of images coming from the movie Sarafina! ${ }^{115}$ dedicated to the young protagonists of the Soweto student riot of 1976 in South Africa during the apartheid era, after a government decree imposed Afrikaans as a co-official teaching language along with English. This episode, the last of a long series of Afrikaner impositions, was perceived as a part of the logic of segregation.

Drawing inspiration from all those events, Orangutan is a powerful invitation for all $2 \mathrm{G}$ people to overcome racial barriers and prejudices and to fight with the same perseverance as their African brothers to obtain civil rights in Italy. Given the deep awareness, consciousness, and attention paid by Karima $2 \mathrm{G}$ in her productions when it comes to the history of the African diaspora, it was important for me to ask her how she feels about looking back, fifty years after Selma, at the struggles that led to the Voting Right Acts and, consequently, to the overcoming of the final barriers preventing African Americans from accessing full citizenship rights. Her words problematize a vision of the African American diaspora and of the Selma march-calling for a distinction between different kinds of African diasporic peoples:

I think African Americans have their own history, which can definitely teach us something, but we need to avoid identifying ourselves in a history of an era that is totally different from ours. What unites all diasporic Africans across the world is the sense of belonging to Africa: we know she is our motherland, but we also know that nowadays we need to free ourselves from the chains

114 In 2014, Lega Nord members from Lodi and Padua actually poured pig urine on lands destined for the building of a mosque in order to prevent the building from being erected.

115 Directed by Darrell Roodt, released in 1992. 
of a painful past, which does not allow a person to feel completely free. We need to realize that each African, first, second, third generation and so on, has her/his own experience and uniqueness. For this reason, indeed it is necessary to face the issues of the refugee, of the immigrant and of the second generations, like me, always being careful not to discriminate each other. I am an Italian of African descent and I want to be recognized for who I am. ... Selma was a protest ended up in a blood bath and, for as useful as it could have been back then for African Americans and for the whole humankind, I am afraid it is not as useful for diasporic Africans living in Europe today. I believe in revolutions, but not in violence. We have been raped through deportation, we have been raped through slavery, we have been and still are raped in different forms by colonialism. I think the time has come to stop all this violence and to concentrate on the challenges we face today. In Italy there is a whole reality that has been hidden and is now asking to be recognized as the new representative of this nation: I am talking about second generations. This is the present of Italy, and will increasingly be its future. (Personal interview)

Karima 2G's words unconsciously recall the thought of crucial theorists of the diaspora, such as bell hooks, Stuart Hall and Paul Gilroy, who dedicated most of their work to the theorizing and re-thinking of the concept and of the places of the African diaspora, as well as of the impossibility of an essentialist representation of Blackness as a structure of identity to be used as a base to build one's subjectivity.

\section{Karima 2G's Transcultural Aesthetics: Performing Race, Ethnicity and Bunga-Bunga Education}

Embedded in such a context, Karima 2G's narrations and raps powerfully resonate today as a silent warning for those who have undertaken the task of reinterpreting history-and at times postulate a unification between diasporic Africans and African Americans when it comes to their relationship with the motherland of Africa, confusing their common need to find their roots with an ambiguous and anachronistic Afrocentrism. The need to trace back one's roots is real, but it is not just a nostalgia for Africa, but rather an urgent necessity to highlight those somatic, hematic, linguistic and cultural connectors that tell the story of a diasporic, migrant, and multi-layered African identity, not to be reduced to a banal pan-ethnic identity. All these instances clearly emerge in the song Back to the roots, from the album $2 G$ :

\footnotetext{
Karima 2G Talking to the new Generation:

don't forget about your roots

who you are and where you come from

You don't know where you come from

You don't know where you call home

Who you are?

Back to the roots

Where we belong

Back to the Roots
} 


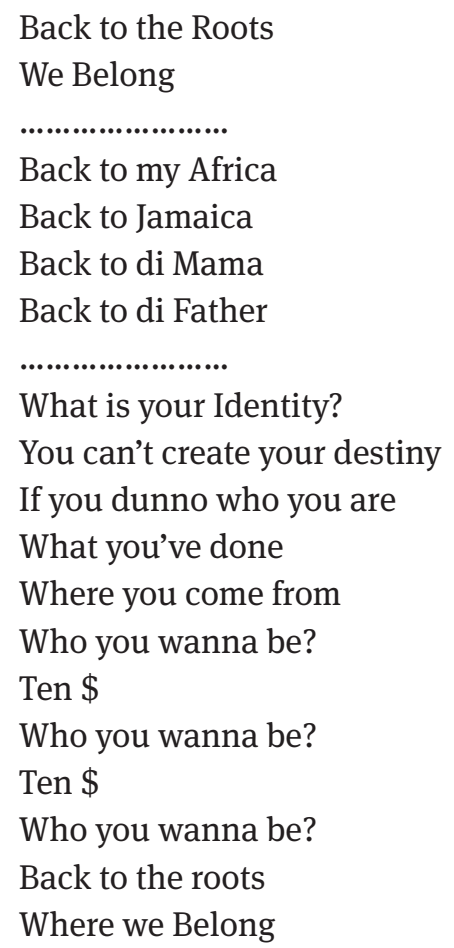

These lyrics deserve comment from a linguistic point of view, as they show some typical features of sounding black, for example in the realization of belong, pronounced as ['brlon] instead of [bI'lon], in the use of the pidgin form di instead of the ("back to di Mama, back to di Father") and, last but not least, the realization of the negative form of simple present dunno ("If you dunno who you are") instead of don't know. More specifically, it might be worth noting that, according to the Electronic World Atlas of Varieties of English, ${ }^{116}$ the determinative article di, as well as the forms dis [this], dem [them], dey [they], seems recurring in many Pidgin English varieties, such as the ones spoken in Cameroon and Nigeria, but are also widespread in creole varieties like the ones of Barbados, Belize, Hawaii, Jamaica and the Krio-Sierra-Leonese, as well as in the early formations of African American Vernacular English. The use of dunno, on the other hand, was observed as not only recurring in Liberian Settler English (LibE), but also in colloquial interactions of both British English and American English. The same goes for the contraction used later on in Karima 2G's lyrics wanna be ("Why you wanna be”). As concerns the realization dunno, as shown by Auer et al. (138) the morphological and phonetic reduction to one unit can imply new pragmatic and rhetorical consequences that go beyond the literal negative meaning, shifting the emphasis on an increased or mitigated stress on the disagreement, which must be evaluated case by case.

116 One of the broadest and most comprehensive research projects available online. It was created between 2008 and 2011 by the Freiburg Institute for Advanced Studies (FRIAS) in cooperation with the English Department of Freibur University, Germany: ewave-atlas.org. 
Karima 2G's aesthetic production also expresses the polyhedral nature of the diasporic experience in the song Refugees (2015), which is a narration of the diverse and unique experiences of the new African sea-crossers seeking the European dream:

Run Run

Run Away across the Nation

Find a solution

Refugees let them go

American dream

Escape by the sea

Come to Europe

Police no big Deal

Stand up Stand up

Don't Bend

Stand Up for the Land

Stand Up and Shouuut!

Somalia-Find a Solution

Sudan-Find a Solution

Nigeria-Find a Solution

EU who? will Find a Solution

Time to live in Peace

No Gun No shit

Sleep in the Camp

The cold is killing me

From Libya to Italy

No Food to Eat

Jump in the Boat

No piece of pepper, No Drink!

Driving to Ethiopia

Outside di Country

Run like Dibaba

Cross the river na di small thing

What I've done?

Just want to have fun

Illegal position, now is my Turn! Run Away

Across di Nation

Find a Solution

Refugees let them go

Dedicated to all the sea-crossers and those who lost their lives in the sea ${ }^{117}$ while trying to reach our coasts, and symbolically released on the World Refugee Day (June 20th 2015), this rap song conveys the expressive power of the sounding black practice,

117 The final scene of the video is an on-screen written dedication: "This song is dedicated to the memory of all those Refugees who are in Europe still Suffering and dying at our borders." 
especially in the refrain ("Run away, across the nation, find the solution, refugees, let them go"), thanks to some phonetic features such as the doubling of the nasal in the realization of run away in [ranna-away], the transformation of the realization of nation as ['neIfa], the replacement of interdental fricatives [th], both unvoiced [think] and voiced [them] at the beginning of a word with the alveolar occlusive [t] e [d], e.g. let them $\rightarrow$ [leddem]. Apart from the expressive power of her words, Karima 2G's video ${ }^{118}$ performance also takes on the symbolic power of her black body, first swimming and then on a boat, which looks rotting and unsafe, just like the ones actually used by the Mediterranean Sea-crossers. The reference to the sea and to the boats used to cross the Mediterranean Sea at all costs tell about the on-going history of diasporas and forced migration, creating bridges between the new African sea-crossers and the deported Africans on the Atlantic triangular route. Nowadays, this history reveals how the collective memory is based on a daily repel-oriented policy, inevitably linked to the violence of deportation, slavery, and colonialism. In this song, like in many others, the visual and linguistic repertoires used by Karima $2 \mathrm{G}$ in her video convey an image of the African in Italy that is based on blackness as a temporary cultural, linguistic and identity performance, and her rap-with the typical characters of the oral black tradition that it features-is a tool for "®esistenza" ${ }^{\text {"119 }}$ challenging and subverting the intrinsic epistemic violence of local and national racist practices and policies. The ability of Karima 2G's music to take on this task and give voice and space to the stories and instances of the second generations-empowered through her music-is an invitation to overcome victim complexes and resignation in order to strengthen their sense of dual or multiple belonging-comes from her use of Pidgin English, as she clearly states during an interview:

It is a language born from the encounter between English, the European colonial language, and the indigenous languages. It developed in different ways and places across the centuries as a consequence of colonialism. It is characterized by a very simple grammar structure, by its peculiar sound and rhythm, and by the mix between indigenous and English words. ... the use of Pidgin allowed me to convey a subversive potential that I could not have transmitted through standard English. (Personal interview)

Not only does the subversive power emanated by Karima 2G's Pidgin English lead the listeners to discover the performative and dramatic power of a language soaked in action, metaphors and similes, but it also invites us to perceive and recognize the creative power of those new linguistic models born around English-a language that is becoming less and less monolithic and more adaptable for negotiation. In such a context, it might be worth embedding Karima 2G's Pidgin English into the theoretical

118 www.youtube.com/watch?v=PexxLXtqROE. Accessed 1 Sept. 2016.

119 Word play created by the author in Italian, which contains the words resistance (resistenza) and existence (esistenza). 
framework outlined by the linguist Alastair Pennycook who, in defining the new varieties of English as Plurilithic Englishes (194), tries to systematize and problematize the principles and conditions that might shape these new variations of English (i.e. "Englishes"). In particular, we accept Pennycook's invitation to free ourselves from the academic obsession for reproducing circles, tubes and boxes-which has been done by linguists such as Braj Kachru and Tom McArthur for a long time-and to take into consideration those trans-idiomatic practices (Jaquemet 257-277) that help to negotiate, rather than prescribe, the linguistic norms, agency, locality, and context of the speaker during an interaction. In the unique case of Karima $2 \mathrm{G}$, another epistemological key to reading her Pidgin English as a trans-idiomatic practice comes from Suresh Canagarajah, who focused his study on the issue of the self and of the way in which postcolonial English speakers can creatively negotiate place, space and the belonging of English to their lives. This allows for spreading a new linguistic model; one that can abandon the enclosure within national 'borders' as its founding base, embracing trans-idiomatic uses and contexts as alternatives to nation-state communities. In this sense, the creative negotiation enacted by Karima $2 \mathrm{G}$ through her Pidgin English reminds one of those specific linguistic dynamics of the diasporic black aesthetics elaborated by Kobena Mercer:

The subversive force of this hybridising tendency is most apparent at the level of language itself where Creoles, patois and Black English decenter, destabilise and carnivalise the linguistic domination of English-the nation-language of master discourse-through strategic inflections, reaccentuations and other performative moves in semantic, syntactic and lexical codes. (63)

The subversive strength of Karima 2G's Pidgin English is reiterated in a central strophe of the song Bunga Bunga, from her album 2G: "DB I'm speaking in Pidgin / You want to understand / Take the African Degree.” What shines through this strophe is not just the Pidgin English pride, but also the effort that interlocutor DB (Deputee Borghezio) is subtly required to make: to acquire the knowledge of African history and culture as the conditio sine qua non in order to gain access to her language and, consequently, her world. It must be said that Bunga Bunga is undoubtedly one of Karima 2G's most sarcastic and desecrating songs-along with the aforementioned Orangutan-in her debut album 2G, not only from a linguistic point of view, but also for the dense visual narration. In fact, she aims to contest some Italian politics based on the "bunga bunga" education-an expression that became popular in Italy and abroad in 2010 to define the alleged sex parties taking place at Silvio Berlusconi's villas while he was Prime Minister of the Italian Parliament. In order to do so, Karima $2 \mathrm{G}$ plays with the Italian collective imagery and uses a full repertoire of racialized, hyper-sexualized and ambiguous themes and bodies, only to subsequently deconstruct it, moving into 
the sub-urban scenery of San Basilio, ${ }^{120}$ one of the angriest and most forgotten ghettoes of Rome. The video opens with the image of a white male dancer, then children cycling along the roads, then colorful laundry hanging from the windows, and this will be the backdrop for most of the video. The camera then focuses on other details, building a Pasolini-like narration: the hardly readable letter B to signal the door of the public housing block, whose walls are crumbling, gates covered in rust and shutters rotting, while among the barely readable graffiti marking every wall it is still possible to see a blurry Italian flag. Against this scenery, Karima 2G and the dancers' (whose skins have different hues of color) are silhouetted, creating a unitary transcultural conjunction of performative bodies and music, made all the more dramatic by the ambiguous and provocative moves and clothing, as well as by the use of two Berlusconi masks worn by a black and seductive woman (maybe referring to one of Berlusconi's 'favorites', Ruby Rubacuori?) and a mixed-race male, clearly participating in the female's seductive moves.

Similar sub-urban scenery can partly be found in Africa, the single released by Karima in July 2016. After interiorizing the concept of African diaspora in the album $2 G$, the single represents the beginning of a new artistic route marked by the powerfulness of the sound, visual and body rituals of gqom, the beat of the new South African generation: "Its strength"-the artist declares-"shed light on a part of me that needed to come out. Every time I listened to a gqom song I could hear the marching pace of a people that won a long and exhausting battle. All this unleashed an interior revolution inside me" ("Karima 2G") ${ }^{121}$ Confirming her attention to the evolution and hybridization of the urban rhythms, Karima $2 \mathrm{G}$ concentrates on the theme of collective identity: "While writing this song, I started seeing myself as a synecdoche of a whole community, united by history, roots, and the intrinsic pride of being children of the same mother: Africa. As much as we can have different destinies and visions, we all come from the same land, we were born in Africa" ("Karima 2G").

Karima 2G's words inevitably recall the concept of beloved communities theorized by bell hooks, proposing the creation of communities in which all the subjects-who come from subaltern ethnicities and cultures, overcoming in-group divisions coming from differences, belonging and exclusiveness-tie bonds of alliance and new social and resistance relations both within the racialized community and with the former oppressors. This need for relations and affective alliances is magically given voice in the song Africa:

I go go go go (x 3)

Where?

120 Also known as "il quartiere della rabbia" (the quarter of rage), given its high crime and homicide rates, San Basilio is a ghetto in the north-eastern area of Rome, between via Nomentana and via Tiburtina, right next to the A90 motorway (commonly referred to as Grande Raccordo Anulare).

121 From the press release accompanying the single release; translated from Italian by the author. 
I go go go go

Some People want go

Some people want to stay

Some people want to be the same

Some people want to change

Some people got in trouble

Some people find the road

Some people got the chance to

Some people had enough

Some people have to learn

that the race is not the case

same blood same land

we come from the same place

Born in Africa

We were born in Africa (x 3)

Please open your eyes

is time to realize

that you're fighting your own Mother, Sister

Break the law, put a stop to the injustices

Let the children live in peace

Please open your eyes

find yourself in the mirrow, there's a hero

who was born in Africa (x 3)

Violence brings violence

Goverment keep silence

I am save from the darkness

proud of my blackness

Political Oppression can create discrimination

pretending not to see the criminal intention

God forgive they don't know what they are doing

Just tell them that we all come from the mother land

The song that Karima $2 \mathrm{G}$ dedicates to Africa is not just a simple exaltation of her origins, but is also an appeal to the "beloved communities" that share the same blood ("Same blood, same land. We come from the same place. Born in Africa. We were born in Africa") and a statement concerning the implications ("political oppression can create discrimination, pretending not to see the criminal intention") of historical processes like colonialism and imperialism, the real cause of the modern diasporas scattered across the world today, as well as the countless civil wars taking place. Talking to the sons and daughters of colonial diasporas, both ancient and modern, her singing encourages awareness ("please, open your eyes"), clear statements ("just tell them that we all come from the motherland") and taking a stand against violence ("sister, break the law / put a stop to the injustices"), thus outlining a new way of coexisting by creating communities held together by common purposes, rather than common ethnic or racial features ("some people have to learn that race is not the case"). The faith that Karima $2 \mathrm{G}$ has for the beloved communities, as intended here, 
can be traced back to her family history and to the bonds that her parents have with Africa, which can be found in her own words:

My parents arrived in Italy in 1978, for work purposes. My father was called by the Liberian Government, asking him to move to Rome and work for the Liberian Embassy there. My parents quickly packed up, leaving behind my eight-month-old sister Comfort (who lived with our grandmother until 1991, when she joined us in Italy). It was not easy for them to make this choice, but they had to. I only understood why they did it in 2013, when I first went to visit Wongbeh Town, my father's village. It is so distant from the city that it overlaps with the forest. Leaving that place is a real venture. The bond with one's land and community is strong and ancestral. In order to leave the village, you need an authorisation from the whole community, who gives the approval only if all of its members think that leaving is an act of devotion and responsibility towards the community itself. It is indeed an agreement foreseeing a reroute to the origin, bringing something new from the outside. My parents were the very first, in their respective communities, to leave their village and move to Europe. I came to the conclusion that human beings can travel the world, do great things and be recognized as individuals, but the full realization can only be obtained when going back to one's own land, one's own community. (Personal interview) ${ }^{122}$

This powerful love bond between Karima $2 \mathrm{G}$ and Africa is particularly surprising when one thinks that Karima $2 \mathrm{G}$ was born in Italy (her real name is Anna Maria) and she only went to Liberia a few years ago for the first time. The uniqueness and the complexity of this "journey back home" are linked to the narrative strength by which her parents told her about Africa since she was a young girl:

I still remember the stories my mother would tell me when I was little. I was very curious and her stories took me there, in that land that I already felt like it was mine. In English, sprinkling it with some Italian words here and there, Liberia was passed on to me, not just narrated. If the fairy tales I was told at school would make me travel with imagination, my mother's stories were a direct transmission, as if I was right there right then. My mother passed on to me an unambiguous system in which everything is connected and interdependent. I have never been in Snow white's village and I never will, while I actually did go in Liberia. The most indelible stories for me are those about my father's village, where snakes were great friends of children. My mother had this great ability to take you to another place through her voice. I barely heard the words. What I lived were images, chants and sounds. The recurring sound were the drums. Still now, I believe that those percussions I heard were a call. (Personal interview)

In this intimate and familiar narration, Africa acquires an imaginative and figurative value, which can be perceived and given a name-irremediably evoking what Edward Said called "imaginary geography and history" (61). While being aware that there has never literally been a journey back home and that the land of her parents has somehow changed today, Karima 2G's Africa does not have a real territorial border: "wherever your feet are, that is Africa” (Personal interview).

122 This quote, like the following, refers to the interview carried out by the author with Karima 2G in September 2016. 


\title{
3 Blackness Is (Not) for Real: Afro-Mediterranean and Transatlantic Diasporic Vernacular Aesthetics
}

\author{
Rather than breaking with the Black past, Hip-Hoppers seek to connect with past verbal \\ traditions and to extend the semantic space of Black lingo by adding a contemporary flavor. \\ They are not merely imitating and reproducing the past, but grounding themselves in it as \\ they seek to stamp their imprint upon the Black tradition.
}

(Smitherman 233)

Geneva Smitherman's words are central for this section, as they forecast one of the fundamental issues of any route tracing back the history of rap as an emblematic example of the diaspora vernacular aesthetics, concerning the exotic relationship between music and history, culture and art, oral transmission and memory. The aesthetics to which rap belongs has a distinctive profile because it cannot stem from a deliberate and rational evaluation of the product, but rather from an inevitably subjective interpretation of the mimesis function of the performance, enacted in the processes of resistance and protest-towards emancipation, belonging or autonomy from the city. Thus, having such aesthetic aims, rap can be part of the "counter-culture" elaborated by Gilroy to define the artistic expressions of the African diaspora, gathering around the concept of Black Atlantic-used to historically configure a cosmopolitan, hybrid, and delocalized space that is cultural and social, which not only includes the traditional slave route across the Atlantic, but also the experience of the immigrant communities in postcolonial Great Britain. The theoretical challenge presented here is to inscribe the experience of the Afro-Mediterranean diasporic people, like Karima 2G, into the concept of the Black Atlantic. Gilroy himself allows this operation, since his intention was to create a common background to re-define cultural identities and alternative policies to the absolutist and essentialist ones, their specificity being/creating a diasporic black culture intended as a transnational form of cultural creativity. Here, a new diasporic aesthetics emerges, articulated around new social and cultural morphologies, overcoming the epistemological limits of ethnocentrism and giving visibility to other stories and dissonant voices, blurring the borders of modern nation-states and shaping the subject within new concepts of citizenship. Such aesthetic productions trace new creative routes, in which the need for spatial collocation coincides with the awareness that being out of place and out of space is the real dimension of living and feeling.

Thus conceived, the diasporic vernacular aesthetics have become, in the words of Gilroy, "formations of opposition," which means anthropological places and logos bringing along traces of origins, memory and of transnational and creole aesthetics into contemporaneousness. On one hand, these formations have fought to "resist" and subvert the most common cultural stereotypes used to enclose black culture, 
namely essentialist ethnic or national definitions; on the other hand, they fought to re-contextualize the experience and the aesthetic products of the transatlantic and Afro-Mediterranean diaspora as alternative form(ula)s of existence-trying to escape from all forms of submission and all forms of socio-cultural hegemony. The result of this process of transculturation has led artists like Karima $2 \mathrm{G}$ to trace back their root work - that is to say in her case the expression of her black culture of origin, Liberia, and of her land of birth, Italy, activating a route of retrieval and return to the roots, while problematizing the contradictory interstices of the racial system centered on race as an attribute, having blackness as its referent. Those symbolic routes that trace back the origins invoke a journey back to the roots, not only as a geographical place, but also as a state of mind, a horizon made up of traditions, stories, and values, but also conflicts and contradictions. The experience of the African diaspora, as expressed in Karima 2G's Afro-Mediterranean aesthetic productions, is not defined by essence or pureness, but by the awareness of necessary heterogeneity and diversity, as well as by a conception of identity that lives with and through difference; it is defined by hybridity.

Starting from the analyses of these Karima 2G's literary and musical productions, the aim here is to theorize identity as something that comes into existence within representation and is able to give visibility to new kinds of subjects-allowing the articulation of a narrative discourse that is also sociological and anthropological, and talks about race and blackness beyond dichotomies such as black/white, racist/ racialized. Thus, the color line is redefined and re-oriented towards a Black Italian imagery that takes into account the ways in which Italians-and especially those from the south-were considered white ethnics, classed as "dark whites" in the racial hierarchy of United States from the late nineteenth to the early twentieth century.

The complexity and the interweaving of the issues and of the identity equivalences between Italians/dark complexion, eyes and hair, Mediterranean blood/ African blood, black/"terrona"123 mother, Sicilian/black/African have problematized Italian whiteness, creating an ambiguous cultural and racial perception, whose origins can be linked to the short distance between Sicily and Africa, to the invasion of Italy by Hannibal during the Second Punic War, and to the Arabic domination of numerous Italian areas during the 9th century. Once arrived in the United States, and clueless about the existence of a color line, Italians lived through complex and contradictory race experiences, being highly discriminated against and even lynched, ${ }^{124}$

123 Terróne (f. terróna) is a derogatory term (at times used as a joke, depending on context but especially when used by its usual addressees as a form of re-appropriation) used by Northern Italians to define Southern Italians. It derives from the Italian word "terra" (meaning "land," "ground" but also "Earth") and it refers to the early days of the unification of Italy, when southern Italy mainly consisted of rural areas.

124 Lynching was usually perpetrated against African Americans, but Italian Americans were often victims too. The discrimination against the two groups tended towards unification, as linguistically 
but also experiencing the racial privilege of whiteness, as recently narrated in the milestone study Are Italians white? How Race Is Made in America (Gugliemo and Salerno). The racialization described by these authors mainly concerned immigrants from Basilicata, Calabria, Campania, Apulia, and Sicily, rural regions of south Italy with a history of colonial exploitation and subaltern politics, where the attribution of a dark complexion was due to the association with rural laborers. ${ }^{125}$ These excavating operations, which permeate transatlantic and Afro-Mediterranean diasporic aesthetic productions, can be read as re-memory ${ }^{126}$ practices-a term coined by Toni Morrison-which means the reconstruction and transmission of historical memory by speaking about old and new migrations in the ever-increasing trans-ethnic context of the present time. By breaching the consolidated and hierarchal binary simplifications of the concept of race, and revealing the artificial and circumstantial nature of each and every identity and political construction, Karima 2G's musical narrations contribute to the re-attribution of semantic meaning of interculturalism. Indeed, it becomes the main tool for unveiling the power strategies of assimilation, enacted by hegemonic and mono-cultural languages and narrations, and fosters practices of resistance, where ethnic differences remain and are not annihilated by a single language/culture. Her artistic productions reflect upon the way in which contemporary migrant and diasporic cultural production creates a sense of cultural belonging that strongly questions the attribution of citizenship based on biological criteria, and formulates new ways of conceptualizing the intersections between whiteness, blackness, and Italianness. Hence, based on such premises, blackness as a race referent stops being a category that refers to a single essence and becomes floating and openly significant, fictional, and artificial, which in turn triggers several complex issues, like the ones proposed by the Critical Race Theory and discussed in the Italian context by Anna Scacchi: race is but an illusion, a false perception of difference between human beings, a label imposed onto certain groups-a lens through which we can look and a sign that can be inhabited. Some of the answers in this chapter, though still partial,

confirmed by the racist language used by the whites who, among the others, used the label Guinea for both African slaves and their descendants and Italian Americans (starting from the beginning of the 20th century). Not many people are aware that the label Nigger, used by white US Americans to belittle African Americans, was also used by sugar cane plantation owners to address Sicilian labourers (Guglielmo and Salerno 27).

125 This theory was for a long time supported by the main Positivist anthropologists of Italy, according to whom the Mediterranean southern Italians, with their darker features, were a separate race from the Aryan northern Italians, who have fair features. The cause of the difference was attributed to the Mediterranean Italians having "inferior African blood.” According to those anthropologists, the geographical position of southern Italy, at the crossroads of Africa, Europe and Asia, had generated a people of "innate racial inferiority." For more information see: Niceforo; Lombroso; Sergi.

126 For an analysis of translation as a re-memory practice, and in particular in its articulations with gender and race, see Taronna, "Writing." 
were provided through the analysis of the Afro-Mediterranean and transatlantic diasporic vernacular aesthetics. The analysis has revealed the emergence of elements concerning a discourse upon blackness and race intertwined with a reflection concerning the new forms of Italianness, which need to be re-defined through a comparative approach, where the color line discourses coming from the United States interact with the Italian ways of talking about language, identity and race.

\section{Conclusion}

The ethno-socio-linguistic analysis carried out here leads to a recognition of Black English as a new cosmopolitan language practice that can connect Italy and the United States, Africa and the Mediterranean, metropolitan cities and peripheries, and diasporic, migrant and postcolonial subjects, who can express their critical space through music, art, literature and cinema. It is an imaginative/imaginary space where, as Said put it, territories overlap and stories intertwine, pushing us beyond the objective and physical limits of self-referential aesthetics that the West has, at times, used to narrate itself. Given such a complex frame of reference, the theoretical reflections on Karima 2G's Black English and on the cultural identities and aesthetics that are linked to it have once again confirmed the idea of language as an interstitial space that is encountered by the speakers while they experiment and project their creole linguistic repertoires into a transformative social dimension. Actually, by breaking the rules governing the normative use of standard English, migrant, postcolonial and diasporic subjects who have chosen to use varieties like Black English or Pidgin English in different contexts and with different communicative purposes, have managed to express and convey the potential of their language in terms of aestheticpolitical desirability.

In conclusion, the linguistic reflections proposed in this chapter encourage an innovative theoretical and methodological approach, including analyses concerning the plurality and pluricentrism that characterize English nowadays, to the growing and complex polyhedral nature of its contexts of use. Only an awareness of the need for alternative methods and re-readings opposing the monolithic and hegemonic vision of English language use can lead to an affirmation of the interdisciplinary and intercultural space that Ortiz defined as transculturation, namely a zone in which different languages and cultures converge syncretically, without hierarchies or censorship. Based on such premises, both African American diasporic aesthetics as well as Karima 2G's African Italian sense of identity can become models of transcultural communication in an Italian context, where the Italianness of second generations has to take into account national identity together with loyalty to family bonds, religion, and the ever-evolving sense of ethnic and cultural belonging. Being Italian today is a more complex process of identity formation, one that needs to take into account 
blood bonds in addition to place of birth and legal residency. It is possible to infer that the cultural practices of second generations develop in a double time dimension, to be intended as a re-memory of a forgotten past and as a practice of democratic coexistence in the present, reifying an unheard declination of the concept of authorwith consequences that cross national and linguistic borders. In their works, migrant and diasporic writers deal with the discourse of race and color in Italy beyond the binary oppositions black/white, racist/racialized, questioning the socio-cultural and identity dynamics where the re-production of power, resistance, inhabitation and reinhabitation of the word race in its new semantic meanings coexist. With the production of their own cultural aesthetics, second-generation artists and writers breach the collective imagery of national identity, re-shaping Italian culture and society in a transcultural and translingual perspective.

\section{Works Cited}

Auer, Peter, et al. Dialect Change: Convergence and Divergence in European Languages. Cambridge UP, 2005.

Canagarajah, Suresh. Translingual practice. Global Englishes and Cosmopolitan Relations. Routledge, 2013.

Creese, Angela, and Adrian Blackledge. "Translanguaging in the Bilingual Classroom: A Pedagogy for Learning and Teaching?” The Modern Language Journal, vol. 94, 2010, pp. 103-115.

Gilroy, Paul. The Black Atlantic. Modernity and Double Consciousness. Verso, 1993.

Giuliani, Gaia. "La sottile linea bianca. Intersezioni di razza genere e classe nell'Italia postcoloniale." Studi Culturali, vol. 2, 2013, pp. 253-344.

Guglielmo, Jennifer, and Salvatore Salerno, editors. Are Italians White? How Race Is Made in America. Routledge, 2003.

Jacquemet, Marco. "Transidiomatic Practices: Language and Power in the Age of Globalization." Language and Communication, vol. 25, no. 3, 2005, pp. 257-277.

Juang, Richard M., and Noelle Morrissette, editors. Africa and the Americas: Culture, Politics, and History. A Multidisciplinary Encyclopedia, vol.1. ABC-CLIO, 2008.

Karima 2G. Personal interviews. Feb.-Sept. 2016.

“Karima 2G: il video di 'Africa', una rivoluzione innescata dal nuovo ritmo sudafricano." mescalina.it, 01 July 2016, www.mescalina.it/news_musica/13857. Accessed 10 Aug. 2017.

Lombroso, Cesare. L'uomo bianco e l'uomo di colore: lettere sull'origine e la varietà delle razze umane. F. Sacchetto, 1871.

Mercer, Kobena. Welcome to the Jungle: New Positions in Black Cultural Studies. Routledge, 1994. Niceforo, Antonio. L'Italia barbara contemporanea: studi e appunti. Remo Sandron, 1898.

Ortiz, Fernando. "Del fenómeno social de la transculturación y de su importancia en Cuba." Contrapunteo cubano de tabaco y del azúcar. 1940. Biblioteca Ayacucho, 1987, pp. 92-96.

Pennycook, Alastair. "Plurilithic Englishes: Towards a 3D model."Global Englishes in Asian Contexts, edited by Kumiko Murata and Jennifer Jenkins, Palgrave Macmillan, 2009, pp. 194-207.

Said, Edward W. Orientalism. Penguin, 1978.

Scacchi, Anna. "Nodi e questioni intorno al 'parlare di razza." The European South, vol. 1, 2016, pp. 63-73.

Sergi, Antonio. Ari e Italici. Bocca, 1989. 
Singler, John Victor. "Liberian Settler English and the Ex-Slave Recordings: A Comparative Study." The Emergence of Black English: Text and Commentary, edited by Guy Bailey, Natalie Maynor, and Patricia Cukor-Avila. John Benjamins, Amsterdam, 1991, pp. 249-274.

Smitherman, Geneva. "Word from the Hood: The Lexicon of African American English." The Structure of African American English, edited by S. Mufwene Salikoko et al., Routledge, 1998, pp. 203-225.

Taronna, Annarita. "Black power is black language. Le lingue del ghetto come pratiche di ®esistenza." Iperstoria-Testi Letterature Linguaggi, vol. 8, Autunno/Fall 2016, pp. 80-96.

--. "Writing on Race and Sexuality in the Harlem Renaissance: Translation as Re-telling and Rememory." Sexualities in Translation, edited by Christopher Larkosh-Lenotti, St. Jerome Publishing, 2012, pp. 10-32. 